\title{
Dissertation Summary Elites and Economic Policies in Indonesia and Nigeria, 1966-1998
}

\author{
Ahmad Helmy Fuady \\ Research Centre for Regional Resources \\ Indonesian Institute of Sciences
}

This study analyses why Indonesia and Nigeria experienced contrasting development trajectories from 1966 to 1998, despite their similar socioeconomic and political conditions. During this period, Indonesia was more successful than Nigeria in managing economic development. What did the Indonesian government do to successfully manage the economy that the Nigerian government did not do? Why did policy elites in the two countries choose different policies while facing similar economic challenges? The analysis focuses on these two questions. First, it examines the economic policies that led to the diverging economic performance of the two countries. Second, it examines potential factors that might explain this contrast in policy.

Unlike previous studies that analyse the divergence using an institutional approach, this study proposes an alternative view: that Nigerian policy-makers were mistaken or misguided about what was necessary to achieve sustainable and equitable economic growth. The personal background of top economic policy-makers is shown to be important for economic development in a developing country. A contrast in economic performance arose under roughly similar institutional arrangements in Indonesia and Nigeria, and the contrast arose from the response of

1 This $\mathrm{PhD}$ dissertation has been publicly defended on 19 April 2012 as a requirement to obtain a doctorate degree at the Faculty of Social and Behavioural Sciences, Universiteit van Amsterdam, The Netherlands. 
policy-makers to institutional challenges. Without neglecting the role of institutional arrangements in shaping policy decisions, this study shows that knowledge and beliefs acquired by policy-makers through their life experience and educational training were decisive for the course of development.

Using primary data from interviews as well as written sources collected during my fieldwork in Indonesia (July 2008-March 2009) and Nigeria (March-September 2009), the analysis focuses on two points in time when the two countries started to show a divergence in economic performance. First, the late 1960s, when the Indonesian economy started to grow rapidly and continuously with the agricultural sector as the engine of growth, while the Nigerian economy failed to grow because of the neglect of agriculture. Second, the early 1980s, when, with oil prices starting to drop, Indonesia embarked on export-oriented industrialization with a series of liberalization measures, while Nigeria failed to depart from its import-substitution strategy.

In Indonesia, economic policy-makers came from a very narrow range of society and had a roughly similar background. They were similar not only in educational background, but also in terms of generation, social origins, life experience, as well as ethnicity. Meanwhile, Nigeria's policy-makers came from more diverse origins. They were appointed to the cabinet to meet requirements of ethnic, regional and religious representation designed to reflect the federal character of the state. The institutional view suggests that diversity and fragmentation of the Nigerian elite made it difficult for them to arrive at a consensus within the government, which then led to inefficient policies. This study, however, shows that there was no significant difference in development vision among Nigerian policy-makers. Regardless of their ethnicity or religion, they were all particularly interested in transforming the economy into a self-reliant, industrialized, and state-driven economy. The conclusion to be drawn from this is that regional, ethnic and religious differences in Nigeria did not lead to difficulty in forming a consensus about the overall development direction. 
Along with political fragmentation, political pressure on policy-makers and regime instability have been seen as major obstacles to development in Nigeria. However, the contrasting trajectory of development in Indonesia and Nigeria suggests an alternative argument. The economic policy-makers in both countries were working under military regimes. My interviews with members of the policy elites in the two countries show that they were in fact sufficiently insulated from military and political pressure. This all supports the argument that economic policies implemented in each country reflected policy-makers' ideas and vision of development, and were not merely a result of institutional problems such as elite fragmentation or political pressure. Nigeria's policy-makers may have come from a more diverse background than Indonesian policy-makers, but their vision of development was not fragmented along the lines of diversity.

Three major policy contrasts between the two countries are highlighted: rural or urban development orientation, exchange-rate policy, and industrialization policy. Since the late 1960s, with agriculture as the engine of growth, Indonesia's economy grew rapidly, accompanied by a steady reduction in poverty. By contrast, the Nigerian economy slowed down. This was triggered in particular by the neglect of agriculture, which provided the largest contribution to the Nigerian economy. Indonesian policy-makers put rural-agricultural development as their first priority, while Nigerian policy-makers preferred industrialization at an early stage of development.

Indonesia's policy elite argued that agricultural development would increase the income of the majority of the country's population, which in turn would increase demand for the industrial sector that provided supplies needed by farmers and therefore would increase national income. Increase in domestic food production was also considered desirable in order to reduce food imports and to reduce the threat of inflation resulting from the pressure of rising food prices. Meanwhile, Nigeria's policy-makers prioritized development of the urbanmanufacturing sector, which they believed would bring with it growth, 
development and modernization. Without a rapid increase in valueadded in the manufacturing sector and sufficient transfer of technology, Nigerian policy-makers believed that the economy would remain merely a supplier of raw materials for the developed world.

Analysis of industrialization policy in the two countries shows that Indonesia's policy-makers were very pragmatic in their way of thinking. They believed that market forces were necessary for the economy to progress, but they also realized the importance of government intervention to handle market failures. The pragmatism of Indonesian policy-makers is also shown by swings in policy from time to time. In Nigeria, the economic orientation of the policy elite did not really change much during the decades after independence. From the time of independence onward, policy-makers continued to be obsessed with promoting value-added industries through an active role of government.

In the early 1980s, the Indonesian economy embarked on an exportoriented industrialization strategy that sustained the rapid growth of the economy. A series of liberalization measures was introduced and made the manufacturing sector the engine of exports, surpassing the oil and the agricultural sectors. By contrast, Nigeria's policy-makers half-heartedly liberalized the economy and the economy deteriorated further after the 1980s; the economy grew very slowly, GDP per capita decreased, and manufacturing industries ran into difficulties. Indonesia's policy-makers were more open to the international market than Nigerian policy-makers, who preferred a regulatory nationalism with a strong role for the government. While Nigeria's policy-makers held on to a nationalist economic way of thinking, Indonesia's policymakers pragmatically adopted market-oriented policies.

The contrast between a rural-based and an urban-based development vision, as well as between market-oriented pragmatism and regulatory nationalism, can be seen clearly in the two countries' macroeconomic, particularly exchange-rate, policies. Indonesia's policy-makers devalued the rupiah several times, which increased the competitiveness of Indonesia's exports on the world market. In contrast, Nigeria's 
policy-makers maintained the overvalued naira, which caused exports to deteriorate, and further stimulated import dependence as well as reliance on oil revenue. The decision not to correct the naira to its market value jeopardized non-oil exports, making them lose competitiveness on the international market. The agricultural sector, which had previously contributed the majority of the country's exports, was priced out. Moreover, the agricultural sector, on which most of the population relied, suffered from import competition. In the early 1980s, for instance, Nigeria heavily imported food products to satisfy demand by urban consumers.

From a political economy point of view, the decision of Nigeria's policy-makers not to devalue the naira shows that they did not attach too much importance to agricultural development in rural areas. They were more concerned about how devaluation might harm the urbanindustrial sector, which relied heavily on imported raw materials. A strong naira also benefited urban consumers in the short term, at the cost of ordinary Nigerian farmers. In contrast, devaluation in Indonesia helped boost the income of Indonesian farmers who produced export crops, especially in rural areas outside Java.

Without neglecting economic, political and institutional arguments, this study shows that the background of policy-makers is an important factor in the contrast between the two countries. One part of their background is their life experience. Policy elites in Indonesia and Nigeria came from a roughly similar social background. They came from middle-class families, with parents having occupations such as bureaucrats, teachers, traders and traditional rulers; only a few of them came from a peasant background. However, this does not mean that they had no experience of rural living. Most of the policy-makers during the period studied were born in the 1920s or 1930s, when agriculture was the main source of livelihood of the vast majority of the population. However, Indonesian and Nigerian policy-makers learned to perceive the agricultural sector differently. Indonesian policy-makers had learned from their family the importance of improving the lot of peasants. In contrast, Nigeria's elites 
had been taught to move out of the agricultural sector to urban life in order to avoid poverty.

There is also a difference between the two countries in the perceived social and cultural divide between town and countryside. In Nigeria, this cultural divide appears to have been wider than in Indonesia, and there was a tendency to idealize urban living as the standard for modernization. Also, the greater attraction of modern urban life may be partly because development of urban areas in Nigeria is a relatively new phenomenon compared to the much earlier urbanization of Indonesia.

Policy elites in Indonesia and Nigeria also had different experiences of nationalism and struggle for independence. In Indonesia, many policy-makers during their formative years had participated in guerrilla wars, where they had to mingle with the rural population in order to disguise themselves from the colonial armed forces. Nigeria's elites did not experience a struggle for independence where they had to mingle with peasants. In contrast, during their formative years prior to Nigerian independence, they experienced an elite urban lifestyle. This does not mean that Nigeria's policy-makers were less nationalistic than Indonesia's policy-makers, but they seem to have had a different attitude toward rural life and a different vision of modern life.

This study also shows the importance of the practical experience of policy elites. The economic and political chaos during Sukarno's period provided a strong lesson for Suharto's team of economists not to make similar mistakes. Therefore, they controlled inflation, ensured food sufficiency, increased the income of the majority of the population through agricultural development, and opened the economy to the world market. They recognized that economic insulation, imprudent macroeconomic management, and neglect of the agricultural sector would only harm the Indonesian economy. In Nigeria, the nature of the economic crisis made it difficult to recognize it as policy failure. The decrease in agricultural development was slow, and Nigeria's staple foods, such as yam and cassava, remained widely available domestically. This was different to the nature of the crisis in Indonesia in 
the 1960s, which could only be blamed on wrong policy. Deteriorating economic conditions in Nigeria in the 1980s could easily be blamed on decreasing oil prices. Therefore, Nigeria's policy-makers were able to keep on neglecting the agricultural sector, and maintaining regulatory nationalism at the expense of the majority of the population.

In addition, Indonesia's policy-makers had a practical understanding of the radicalism of small-scale farmers. They had experienced the ability of peasants to organize themselves, and to be organized as a sociopolitical force, because this had been demonstrated in the beginning of 1960s by the Indonesian Communist Party. There is a tradition of rural revolt in Indonesia, which had the potential to be dangerous for Suharto's New Order regime. In contrast, Nigeria's policy-makers lacked such experience of rural revolt.

The educational background of policy-makers is another important factor in their contrasting policies. Indonesia's policy-makers were technocrats with a policy-oriented economics background. Most of them had formal training in economics in the United States, where they learned about economic policy tools. Their background in policy-oriented economics made them pragmatic, less attached to any ideology, in their policy choices. They could at once be very liberal and also interventionist, depending on the needs of the economy. Their empirical and policy-oriented, rather than polemical and philosophical, mindset was very important in their choice of policies. Nigeria's policymakers had been educated in a greater diversity of subjects, such as law, administration, education and politics. Although a number of Nigeria's policy-makers had also been trained in economics, it was mainly in the political economy tradition of Europe. Because of their educational background, Nigeria's policy-makers often believed that economic calculations should not take precedence over political considerations.

The differences in educational background influenced not only the mindset of the policy elites, but also their dealings with other actors in the policy arena. This can be seen in their relationship with international organizations, such as the IMF and the World Bank. The shared language 
of economics made it easier for Indonesia's policy-makers to build a partnership with IMF and World Bank officers. In contrast, Nigeria's policy-makers saw these international organizations as external powers representing a new form of colonialism and therefore hesitated to work with them.

This study suggests a recipe for sustainable and equitable growth. First, the government should prioritize investment in the agricultural sector. Second, the government should attempt to incorporate the majority of the population in development programs. Third, the government needs to carefully integrate the domestic economy into the world market, by providing more incentives for export-oriented industries. Fourth, macroeconomic management, particularly to keep the exchange rate realistic, is important not only for export products to be able to compete on the international market, but also to help avoid dependence on imports. 